INVITED REVIEW ARTICLE

\title{
高齢者非小細胞肺癌の治療の現状と展望
}

\author{
山口正史1
}

\section{The Therapeutic Approaches Applied in the Treatment of Non-small Cell Lung Cancer in Elderly Patients}

\author{
Masafumi Yamaguchi1 \\ ${ }^{1}$ Department of Thoracic Oncology, National Kyushu Cancer Center, Japan.
}

ABSTRACT - The improvement of the average life span in recent years has led to the aging of societies worldwide. In this setting, cancer is a major cause of death. Lung cancer, in particular, is a leading cause of death and the average age of patients with non-small cell lung cancer (NSCLC) has almost reached the mid-70s. Obviously, "fragility" is an important aspect in the treatment of elderly patients with NSCLC. In general, elderly patients are considered to have more comorbidities, including - but not limited to-diabetes mellitus, cardiovascular disorders, and respiratory disorders; many patients have multiple comorbidities. On the other hand, "fragility", which can reflect physiological, psychological or social factors, is used to describe conditions that can vary widely, even within the same age group. This often makes treatment decisions difficult. Treatment decisions should be made after considering the balance of risks and benefits; in other words, the balance of life expectancy obtained by the treatment, and the estimated life span of each patient. Needless to say, care should be taken to ensure that the treatment decision reflects the patient's wishes. This review focuses on the treatment modalities and strategies that are applied in the treatment of each stage of NSCLC (i.e., surgical resection, radiation and chemotherapy). Surgical resection is a suitable choice for early-stage NSCLC. At the present time, pulmonary lobectomy (or greater) resection, with the resection of the mediastinal lymph nodes, is the standard treatment for early-stage NSCLC; however, no prospective clinical trials have assessed the risks and benefits of surgery in elderly patients with early-stage NSCLC. The results, in terms of the survival benefit, risk, extent of resection (i.e., lesser resection or standard resection), and the recent results of stereotactic body radiotherapy will be reviewed. Furthermore, this report will discuss the development (based on prospective clinical trials) of chemotherapy or chemoradiotherapy for elderly patients with advanced NSCLC.

(JJLC. 2017;57:739-745)

KEY WORDS — Non-small cell lung cancer, Elderly patients, Surgery, Chemotherapy, Radiotherapy

Corresponding author: Masafumi Yamaguchi.

要旨一一近年の急速な医療の進歩を含む社会情勢の変 化により世界的な高齢化社会を迎え，この状況の中で死 亡原因に占める悪性腫瘍の割合は年々増加している。悪 性腫瘍の中でも肺癌は本邦においては男性で 1 位，女性 では 2 位を占め, その多くを高歯者が占めることは治療 選択においての重要な問題の 1 つである。一般に高齢者 の多くは糖尿病, 虚血性心疾患や呼吸器疾患に代表され る身体機能の低下につながる併存症の存在に加え, 認知 機能の低下を伴う場合もあり，個々の年齢のみならず併 存症などが影響する全身状態が治療選択の決断に影響す ることは論を待たない。治療法の選択においては年齢に
よらず本人の人生観や社会観が反映されるべきである が，特に高齢者においてはその治療により当該年齢から の予測平均寿命に対し十分な予後が期待されるか, 同時 に Quality of Life (QOL) に代表される生活の質にかかる 事項が担保されるか否かが, 治療方針決定の際には重要 となる。本稿においては高歯者者の非小細胞肺癌について 臨床病期 I II 期における外科治療, III 期の局所進行症 例に対する化学放射線療法, さらに IV 期症例に対する 化学療法それぞれについて, 現状と課題を検討したい. 索引用語—— 非小細胞肺癌, 高齢者, 手術, 化学療法, 放射線療法 


\section{はじめに}

世界的に高齢化は確実に進行しており，これに伴い死 亡原因として悪性腫瘍, 中でも肺癌は本邦においても増 加の一途を辿り, 厚生労働省の統計では 2014 年に男性に おいては悪性腫瘍による死亡の 1 位，女性では大腸癌に 続き 2 位となり, 年齢調整罹患率では 70 歳から急増が認 められる。

日本肺癌学会の肺癌診療ガイドラインにおいては 75 歳以上を高齢者と定義しているが, これら高齢者の大き な特徵は呼吸機能や循環動態，筋力などの生理機能の低 下や，糖尿病をはじめとした代謝疾患や循環器疾患，呼 吸器疾患などの治療のリスクとなる併存症の割合の増 加，さらには認知機能の低下などの身体的，心理的脆弱 性である. 実際に米国の疫学調査では 75 歳以上の $94.1 \%$ が 1 つ以上の，また $68.5 \%$ が 3 つ以上の併存症を持つと 報告されている. 1 こうした高齢者の非小細胞肺癌に対 する治療法の選択に際しては様々な因子を考慮する必要 があるが，当然ながら第一義的にはその治療介入により 生存期間の延長が期待されることであり，第二義的には 治療介入による Quality of Life (QOL) の維持などの目的 が治療に際し，予測される合併症のリスクを上回ると推 定されることである。これらの高齢者のリスクについて は，一般的な生理機能検查などに加えて様々な併存症な どの因子を点数化し予後予測因子として検討したCharlson Comorbidity Index（CCI）, 2 これらの因子をょり簡 便にしたSimplified Comorbidity Score（SCS), 3 血清ア ルブミン值と血漿 C 反応性蛋白值から予後予測を検討 した Glasgow Prognostic Score (GPS)，4 日常生活動作, 認知機能，社会経済因子などを包括的に評価する Comprehensive Geriatric Assessment (CGA) 5 などがあり 各種疾患での予後因子としての報告があるが, 肺癌領域 についてはこれらの評価も含めて治療適応の可否を決定 するシステムは未だ確立したとは言い難い. 本総説では, 高齢者の非小細胞肺癌に対する治療における現在までの 知見と今後の課題について検討したい.

\section{I II 期非小細胞肺癌}

日本胸部外科学会の統計では, 本邦の 2014 年の原発性 肺癌切除症例に抢いて 70 歳以上が $41.4 \%$ を，また 80 歳 以上を $12.1 \%$ が占め, 6 この割合は経時的に増加してお り今後さらに高齢者の割合が増していくものと推測され る. 臨床病期 I II 期の非小細胞肺癌症例には根治的外 科切除が治療法の第一選択であることは論を待たない が，先に述べたように呼吸機能をはじめとした生理機能 や活動性の低下，併存症による生命予後に影響する合併 症を予測，予防することが，手術に際しての喫緊の問題
となる.

非小細胞肺癌に対する近代的な外科切除が確立したの は, 1950 年にChurchillにより肺全摘術と比較して肺葉 切除術の生存が有意に良好であることが報告されて以来 と思われるが, その後 1980 年代には既に高齢者に対する 切除の検討が複数報告されている.この時期の 1989 年に Shirakusa らは, 当時の 80 歳以上の肺葉切除を主とした 非小細胞肺癌切除症例の検討で約 $50 \%$ に不整脈などの 合併症を認め，12\%に術後 60 日死亡を認めたが， 5 年生 存割合が全症例では $55 \%$ ，I期では $79 \%$ であり，当時の 80 歳の平均余命の 6.5 年に対して許容できると報告し た. ${ }^{7}$ 以後, 画像診断や周術期管理, 併存症の治療と管理 などがより進歩してきた現在も，高龄化による生物個体 としての脆弱化が切除の適応を左右している. 現時点に 至るまで高齢者非小細胞肺癌の切除症例の選択, 術式や 周術期管理などについては日常の臨床経験が占める割合 が多いと考えられ，その報告の多くは後方視的検討であ る. 手術の選択については, 当該症例の平均余命に照ら して生存の延長が他の治療法に比して可能と期待され, 術後の QOL や日常生活行動がある程度維持されること が前提となるものと考えられる. Table 1 に, 2000 年代に 報告された症例数が 50 例以上の, 75 歳以上の非小細胞 肺癌に対する切除例について複数の検討を要約した. 8-13 術式としてデータが示されている報告では肺葉切除が $60 \%$ 以上に施行され，次いで部分切除が $16 \sim 26 \%$ に施 行されている。いずれも術後 5 年生存割合は病理病期 I 期について 60〜 75\% 程度と報告されている. I 期非小細 胞肺癌症例に対する積極的縮小手術の是非については, 現在症例集積を終了して観察中の, CT で原発巣の腫瘍 径に対する充実成分の比率が $50 \%$ 以上の IA 期非小細胞 肺癌症例に対する区域切除と肺葉切除を比較した第 III 相試験（JCOG0802）の結果を待たなくてはならないが, 日常診療では既に I 期症例に対し積極的縮小手術として 区域切除を採用している施設も多い。この点について Okami らは 75 歳以上の I 期症例については縮小手術と 肺葉切除の生存に統計学的差違はないと報告して扔 り, 11 術後の肺機能温存による合併症の軽減, QOL の維 持が期待される. また, 現在日本呼吸器外科学会により 「高齢者肺癌に対する外科治療の安全性と有効性を評価 するための多施設共同前向き調查研究」の解析が進行中 である.この研究術前評価項目には CCI, SCS, GPS, CGA による身体機能，認知機能などが含まれ，また 1 次評価 項目は周術期合併症であるが，2次評価項目には QOL の評価も含まれており，その結果が待たれるところであ る.

さらに，近年は一般に肺や末梢のI 期非小細胞肺癌に 対する体幹部定位照射が広く日常診療で使用されるよう 
Table 1. Summary of the Reports on Surgical Resection in Elderly Patients with Non-small Cell Lung Cancer in Which More Than 50 Patients Were Included

\begin{tabular}{|c|c|c|c|c|c|c|c|c|c|c|c|c|c|c|}
\hline \multirow[t]{2}{*}{ Author } & \multirow[t]{2}{*}{ Year } & \multirow{2}{*}{$\begin{array}{l}\mathrm{Pt} \\
(\mathrm{n})\end{array}$} & \multirow{2}{*}{\multicolumn{2}{|c|}{ Age (median) }} & \multicolumn{4}{|c|}{ Surgical procedure (\%) Ad/Sq } & \multirow{2}{*}{$\begin{array}{c}\mathrm{pIA} / \mathrm{IB} / \mathrm{II} / \mathrm{IIA} \\
(\%)\end{array}$} & \multirow{2}{*}{$\begin{array}{c}5 \mathrm{y}-\mathrm{OS} \\
(\%)\end{array}$} & \multirow{2}{*}{$\begin{array}{c}\text { Morbidity } \\
\text { (\%) }\end{array}$} & \multicolumn{2}{|c|}{ TRD } & \multirow[b]{2}{*}{$(\%)$} \\
\hline & & & & & Partial & Seg & Lob & Pn & & & & All & Major & \\
\hline Birim $\mathrm{O}^{8}$ & 2003 & 126 & 74 & $(70-82)$ & 6.0 & 0 & 76.0 & 18.0 & $30 / 47$ & $31 / 45 / 8 / 13$ & 37 & 57 & 13 & 3.2 \\
\hline Brock $\mathrm{M}^{9}$ & 2004 & 68 & 82 & $(80-87)$ & 16.0 & 7.5 & 75.0 & 1.5 & $46 / 20$ & NS & 62 (IA) & 44 & NA & 8.8 \\
\hline D-Ventura $\mathrm{A}^{10}$ & 2006 & 379 & 82 & $(80-95)$ & 20.6 & 7.7 & 65.1 & 6.6 & $43.8 / 37.7$ & $35.7 / 31.4 / 13.7 / 17.4$ & $\mathrm{~N}$ & 48 & NA & 6.3 \\
\hline Suemitsu $\mathrm{R}^{13}$ & 2008 & 146 & 82.6 & $(80-90)$ & 26.0 & 11.6 & 58.9 & 0.7 & $61.6 / 33.6$ & $64.3(\mathrm{pI}) / 9.6 / 15.1$ & 46.8 & $\mathrm{NA}$ & NA & NA \\
\hline \multirow[t]{2}{*}{ Okami J11 } & 2010 & 133 & 77 & $(75-87)$ & 0 & 0 & 100 & 0 & $83.5 / 12.7$ & NA & 74.3 & 19 & 5.1 & 0 \\
\hline & & & 78 & $(75-84)$ & 100 & & 0 & 0 & $66.7 / 27.8$ & NA & 67.6 & 14.8 & 9.3 & 0 \\
\hline Shiono $\mathrm{S}^{12}$ & 2013 & 119 & 77 & $(75-88)$ & NA & NA & NA & NA & $52.9 / 40.3$ & $42.0 / 29.4 / 12.6 / 15.1$ & 68.1 & 34.5 & NA & 0 \\
\hline
\end{tabular}

Partial, partial resection; Seg, segmentectomy; Lob, lobectomy; Pn, pneumonectomy; 5y-OS, 5-year overall survival; All, all morbidities; Major, major morbidities; TRD, treatment related death; NA, not available.

になった。肺癌診療ガイドラインにおいても医学的な理 由で切除できない I II 期非小細胞肺癌に対して根治的 放射線治療の適応があり，さらにI期症例については体 幹部定位照射も権められている(グレード B)。本邦にお いては, 組織学的に診断が確定した I 期非小細胞肺癌に 対する体幹部定位照射の第 II 相試験 (JCOG0403) が行わ れた。全 169 症例のうち 75 歳以上が 110 例であり, Grade 3/4 の有害事象は $10 \%$, 治療関連死亡は認めず 3 年全生存率が $59.9 \%$ と, 良好な安全性と効果を示した. 14 現時点で I 期非小細胞肺癌症例に対する体幹部定位照射 と外科的な切除の優越性を検討した第 III 相試験で完遂

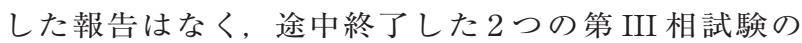
プール解析で体幹部定位照射の予後が良好であったと報 告されているが, この解析対象は 58 例と少なく, また約 $25 \%$ は組織学的診断が得られておらず, 15 結論に達した とは言い難い.しかしながら，米国でのデータベースを 基にした 75 歳以上の症例 51.5\% を含む 9093 例の I 期非 小細胞肺癌症例に対する肺葉切除, 縮小手術と体幹部定 位照射の検討では, 耐術可能であれば肺葉切除が予後延 長に寄与するが, 超高齢者と複数の併存症を持つ症例に は体幹部定位照射が治療の選択肢であることを示唆して おり, 16 今後の照射法や治療機器の進歩が待たれる.

\section{III 期非小細胞肺癌}

III 期の局所進行非小細胞肺癌に対する標準治療は, 化 学放射線同時併用療法である. 米国では Radiation Therapy Oncology Group (RTOG), Eastern Cooperative Oncology Group（ECOG）および Southwest Oncology Group (SWOG) による局所進行非小細胞肺癌に対する放 射線療法または化学放射線療法の第 III 相試験の統合解 析が行われ， 60 歳以下と 70 歳以上の年歯によるサブ セット解析では, 放射線治療の中央生存期間は 60 歳以上 の群で 11.7 ヶ月間に対し 70 歳以上の群では 13.1 ヶ月間
と高齢者に良好であったものの，化学放射線同時併用療 法では 60 歳以下が 15.4 ケ月間であるのに対し 70 歳以 上の群では 10.9 ケ月間と高齢者で劣ることが示され た. 17 他方, 米国の North Central Cancer Treatment Group（NCCTG）により施行された化学放射線同時併用 療法と放射線療法を比較した第 III 相試験での 70 歳未 満と以上の 2 群に層別化した解析からは, 70 歳以上の群 には好中球減少と血小板減少が有意に多いもののその生 存には統計学的差がなく, 年齢は予後因子にならないと 結論している. 18 本邦においては，71 歳以上の III 期非 小細胞肺癌に対するカルボプラチン連日投与併用の化学 放射線併用療法と放射線療法単独を比較する第 III 相試 験が行われ (JCOG0301), 第 2 回の中間解析の結果から 化学放射線療法群が全生存においてハザード比（HR） 0.68 (95.4\% 信頼区間 $(\mathrm{CI}): 0.47 \sim 0.98)$ と 1 次評価項目 を満たしたため有効中止となり, 以後本邦の標準レジメ ンとされている. 19

\section{IV 期非小細胞肺癌}

先に述べたように日本肺癌学会による肺癌診療ガイド ラインでは 75 歳以上を高齢者と定義しているが, また同 時に暦年齢のみで化学療法の対象外とするべきではない （グレードA）とされている，高齢者に対する化学療法の 開発は細胞障害性抗癌剂について行われ, その歴史は 1990 年初頭に始まる。1993 年から 1994 年に施行された ECOG5592 は, IIIB〜IV 期非小細胞肺癌に対するシスプ ラチンとエトポシドを標準治療としてシスプラチンと G-CSF 併用での高用量 $\left(250 \mathrm{mg} / \mathrm{m}^{2}\right)$ のパクリタキセル またはシスプラチンと低用量 $\left(135 \mathrm{mg} / \mathrm{m}^{2}\right)$ のパクリタキ セルの優越性を比較した第 III 相試験であり， 登録症例 の $15 \%$ が 70 歳以上であった。このサブセット解析にお いて 70 歳未満と 70 歳以上では 70 歳以上の群に循環器 毒性と呼吸器毒性が多かったものの中央生存期間は 70 
歳未満の群が 9.1 ヶ月間, 70 歳以上の群が 8.5 ケ月間で 有意差を認めず，また少数ながら $70 〜 74$ 歳と 75 歳以上 で層別化した検討でも中央生存期間は各々 8.4 ヶ 月 9.9 ケ月で有意差を認めなかった. 加えて女性については 70 歳以上の年齢群について QOL の改善が認められたた め, 高齢者に扔いてもプラチナ併用の化学療法を検討す べきと結論された. 201996 年から 1997 年にかけて 70 歳 以上の IV 期非小細胞肺癌を対象に QOL の改善を 1 次 評価項目として支持療法 (best supportive care： $\mathrm{BSC})$ とビノレルビン $\left(30 \mathrm{mg} / \mathrm{m}^{2}\right.$, day 1,8 , q3W $)$ を 比較した第 III 相試験(ELVIS 試験) 21 では, ビノレルビ ン投与群で化学療法による有害事象はあるものの疼痛や 呼吸困難をはじめとした肺癌による症状の緩和と QOL を改善し, かつ 1 年生存率は BSC 群の $14 \%$ に対してビ ノレルビン群の $32 \%$ と有意に生存延長効果を認めたた め, ビノレルビン単剤が高齢者に対する化学療法の選択 肢となった.引き続き 1997 年から 2000 年に 70 歳以上の 非小細胞肺癌を対象に生存率を 1 次評価項目としてビノ レルビン $\left(30 \mathrm{mg} / \mathrm{m}^{2}\right.$, day $\left.1,8, \mathrm{q} 3 \mathrm{~W}\right)$, ゲムシタビン $\left(1200 \mathrm{mg} / \mathrm{m}^{2}\right.$, day $\left.1,8, \mathrm{q} 3 \mathrm{~W}\right)$ とビノレルビン $(25 \mathrm{mg} /$ $\mathrm{m}^{2}$, day $\left.1,8, \mathrm{q} 3 \mathrm{~W}\right)$ とゲムシタビン $\left(1000 \mathrm{mg} / \mathrm{m}^{2}\right.$, day $1,8, \mathrm{q} 3 \mathrm{~W})$ の併用の 3 群を比較する第 III 相試験(MILES 試験) 22 が施行された。この結果, 2 剂併用療法は単剂療 法に比して生存延長効果を示さず, QOL は同程度で 2 剂併用療法には有害事象が多いことから高齢者の化学療 法は単剤が標準とされた。また，ELVIS およびMILES 試験の特筆すべきデータの 1 つは登録された高齢者の約 50〜70\%が何らかの併存症を有していたことを示した 点にもあった。

本邦においては 2000 年から 2003 年に 70 歳以上の $\mathrm{III}$ IV 期非小細胞肺癌症例に対しビノレルビン（25 $\mathrm{mg} / \mathrm{m}^{2}$, day 1,8 , q3W）を対照としてドセタキセル $\left(60 \mathrm{mg} / \mathrm{m}^{2}\right.$, day 1 , q3W) の全生存に対する優越性を検 討する第 III 相試験(WJTOG9904)23 が行われ， 1 次評価 項目の全生存がビノレルビン群で 9.9 ケ月間, ドセタキ セル群で 14.3 ヶ月間 (HR 0.780, 95\%CI : 0.561 1.085) と 有意差は認めなかったものの, ドセタキセル群で奏効率 が有意に高く、また無再発期間もビノレルビン群で 3.1 ケ月間に対しドセタキセル群が 5.5 ケ月間と有意に 延長しており，さらにドセタキセル群では好中球減少症 などの有害事象は多いものの症状コントロール割合も有 意に高いことから，本邦に扔ける高齢者の化学療法の見 なし標準治療はドセタキセルとなった，引き続き同一の 対象にドセタキセル $\left(25 \mathrm{mg} / \mathrm{m}^{2}\right.$, day $\left.1,8,15, \mathrm{q} 3 \mathrm{~W}\right)$ を 対照としてドセタキセル $\left(20 \mathrm{mg} / \mathrm{m}^{2}\right.$, day $1,8,15$, q3W) およびシスプラチン $\left(25 \mathrm{mg} / \mathrm{m}^{2}\right.$, day $\left.1,8,15, \mathrm{q} 3 \mathrm{~W}\right)$ の 全生存に対する優越性を検証する第 III 相試験（JCOG
0207) 24 が 2003 年から開始された。この試験は 2006 年 の中間解析の結果で 70 74 歳の患者群においてドセ夕 キセルとシスプラチンの併用療法が有意に全生存の延長 を示したことから，試験中止となった。しかしながら 75 歳以上の患者群では中央生存期間がドセタキセル群の 11.5 ケ月間に対しドセタキセルとシスプラチン群で 13.6 ケ月間 (HR 0.72, $95 \% \mathrm{CI} ： 0.35 \sim 1.49)$ と有意差はな く, 対照とされたドセタキセルの分割投与の治療効果に 問題があることも示唆された。一方, 2007 年から開始さ れた 70 歳以上の III〜IV 期非小細胞肺癌を対象に施行 された第 III 相試験（JCOG0803/WJOG4307L) 25 では対 照にドセタキセル $\left(60 \mathrm{mg} / \mathrm{m}^{2}\right.$, day $\left.1, \mathrm{q} 3 \mathrm{~W}\right)$ が採用され, これに対するドセタキセル $\left(20 \mathrm{mg} / \mathrm{m}^{2}\right.$, day $1 ， 8,15$, $\mathrm{q} 3 \mathrm{~W})$ およびシスプラチン $\left(25 \mathrm{mg} / \mathrm{m}^{2}\right.$, day $1,8,15$, q3W）の全生存に対する優越性の検証が行われたが, 2010 年に行われた第 1 回中間解析でドセタキセル群の 中央生存期間 14.8 ヶ月間に対し試験治療であるドセ夕 キセルとシスプラチン併用群のそれは 13.3 ケ月間とむ しろ下回っており，無効中止となった．しかしながら WJTOG9904 のそれと同じく本試験に扔いてもドセタキ セルによる中央生存期間は 14 ケ月を越えて良好であり, これをもって本邦の高齢者の切除不能非小細胞肺癌に対 する化学療法の標準レジメンは 3 週毎のドセタキセル単 哓投与となった．またTable 2 に示すように上述の第 III 相試験における単剤療法の中でもドセタキセル単郕では Grade 3/4 の有害事象として好中球減少, 発熱性好中球 減少や血小板減少の頻度が高い報告もあるが, 各々にお いて治療関連死亡割合は $0 \sim 1.3 \%$ であり, 適切な症例選 択と対処により許容可能と考えられる.

これらと同時期の 2006 年から 2009 年にはフランスに おいて 70〜89歳の III〜IV 期非小細胞肺癌症例に対し てビノレルビン $\left(25 \mathrm{mg} / \mathrm{m}^{2}\right.$, day 1,8 , q3W $)$ かゲムシ タビン $\left(1150 \mathrm{mg} / \mathrm{m}^{2}\right.$, day 1,8 , q3W $)$ の単剤療法とカ ルボプラチン (AUC 6, day 1) とパクリタキセル $(90 \mathrm{mg} /$ $\mathrm{m}^{2}$, day $\left.1 ， 8 ， 15, \mathrm{q} 3 \mathrm{~W}\right)$ 併用療法を比較する第 III 相試 験 (IFCT-0501) が行われ, 26 中央生存期間は単剂治療群 が 6.2 ケ月, カルボプラチンとパクリタキセル併用療法 群が 10.3 ケ月（HR 0.64, 95\%CI：0.52〜0.78）と初めて高 齢者に対するプラチナ併用療法の有用性を示した。本邦 では同じく 75 歳以上の非扁平上皮肺癌症例に対しドセ タキセル $\left(60 \mathrm{mg} / \mathrm{m}^{2}\right.$, day 1 , q3W) に対するカルボプラ チン（AUC 5, day 1) とペメトレキセド $\left(500 \mathrm{mg} / \mathrm{m}^{2}\right.$, day 1, q3W) 併用療法の全生存に対する優越性を検証す る第 III 相試験（JCOG1210）が進行中であり，この結果 が待たれる.

しかしながら, 高齢者非小細胞肺癌に対する化学療法 剤の状況も, 2000 年代中頃から臨床適応となった EGFR- 
Table 2. Summary of the Phase III Trials on the Use of Cytotoxic Agents in the Treatment of Elderly Patients with Unresectable Non-small Cell Lung Cancer

\begin{tabular}{|c|c|c|c|c|c|c|c|c|c|c|}
\hline \multirow[b]{2}{*}{ Study } & \multirow[b]{2}{*}{$\begin{array}{l}\text { Registered } \\
\text { period }\end{array}$} & \multirow[b]{2}{*}{$\mathrm{n}$} & \multirow[b]{2}{*}{ Age } & \multirow[b]{2}{*}{ Regimen } & \multicolumn{2}{|c|}{ Survival } & \multicolumn{2}{|c|}{ Adverse event } & \multirow[b]{2}{*}{$\begin{array}{c}\text { PLT } \\
\text { G3/4 (\%) }\end{array}$} & \multirow[b]{2}{*}{$\begin{array}{c}\text { TRD } \\
(\%)\end{array}$} \\
\hline & & & & & $\begin{array}{c}\text { OS (m) } \\
\text { (median) }\end{array}$ & p-value & $\begin{array}{l}\text { NEUT } \\
\text { G3/4 (\%) }\end{array}$ & $\begin{array}{c}\text { Febrile } \\
(\%)\end{array}$ & & \\
\hline \multirow[t]{2}{*}{ ELVIS $^{21}$} & $1996-1997$ & 76 & 74 & VNR & 7.0 & 0.03 & $0 / 3.9$ & / & / & 0 \\
\hline & & 78 & $(70-86)$ & BSC & 5.3 & & / & / & / & / \\
\hline \multirow[t]{3}{*}{ MILES $^{22}$} & $1997-2000$ & 233 & 74 & VNR & 9.0 & 0.93 & $6.1 / 4.8$ & / & $0.4 / 0$ & 0 \\
\hline & & 233 & $(63-86)$ & GEM & 7.0 & 0.69 & $3.1 / 0.4$ & / & $0.9 / 0.4$ & 0 \\
\hline & & 232 & & VNR + GEM & 8.5 & & $5.6 / 2.2$ & / & $1.3 / 0.4$ & 0 \\
\hline \multirow{2}{*}{ WJTOG9904²3 } & $2000-2003$ & 92 & 76 & VNR & 9.9 & 0.138 & $30.8 / 38.5$ & 11.0 & 0 & 0 \\
\hline & & 90 & $(70-86)$ & DOC & 14.3 & & $26.1 / 56.8$ & 12.5 & 0 & 1.1 \\
\hline \multirow{2}{*}{ JCOG020724 } & $2003-2006$ & 63 & 76 & weekly DOC & 10.7 & 0.0384 & $9.3 / 0$ & 0 & 0 & 0 \\
\hline & & 63 & $(70-88)$ & weekly P + DOC & 17.0 & & $29.9 / 0$ & 0 & 0 & 1.6 \\
\hline \multirow[t]{2}{*}{$\mathrm{IFACT}^{26}$} & 2006-2009 & 226 & 77.1 & VNR or GEM & 6.2 & $<0.0001$ & $6.7 / 5.8$ & 2.7 & $0.9 / 0$ & 1.3 \\
\hline & & 225 & $(70-88.8)$ & $\mathrm{CBDCA}+\mathrm{PAC}$ & 10.3 & & $30.9 / 17.5$ & 9.4 & $4.9 / 1.8$ & 4.4 \\
\hline JCOG0803 & $2007-2010$ & 137 & 76 & DOC & 14.8 & N.S. & $20.9 / 67.9$ & 15.2 & 0 & 0 \\
\hline /WJOG4307L 25 & & 139 & $(70-87)$ & weekly P + DOC & 13.3 & & $9.3 / 0.8$ & 0 & 0.8 & 2.9 \\
\hline
\end{tabular}

Age, median (range); NEUT, neutropenia; PLT, thrombocytopenia; Febrile, febrile neutropenia; TRD, treatment related death.

TKI や ALK-TKI を代表とする複数の分子標的薬や免疫 チェックポイント阻害薬の出現により短期間のうちに激 変した。本邦のみならず欧米の診療ガイドラインにおい ても,これらの薬剤の適応となる症例群については適応 となる遺伝子変異の存在やPSで治療の選択が規定さ れ，単に年齢のみでは治療方針は規定されない状況と なった. 本邦では, 肺腺癌の約 $50 \%$ を占める EGFR 変異 症例について 75 歳以上を対象とした第 II 相試験が $2 つ$ 報告されている。NEJ003 試験 27 では 2008 年から 2009 年にかけて EGFR 変異を有する進行非小細胞肺癌 31 例 に対し，ゲフィチニブを投与した。対象症例の年齢の中 央值は $80(75 \sim 87)$ 歳であったが, 本試験での病勢制御 割合は $90 \%$, 無増悪生存期間の中央值は 12.3 ヶ月間で 2 年生存割合は $58.1 \%$ と極めて良好であった． 1 例が間質 性肺炎で死亡しているが主たる Grade 3〜4 の有害事象 も含めて既報のゲフィチニブのデータと遜色ないものと 思われる。 また, JO22903 試験28 は 20 歳以上で PS 0 1 の $\mathrm{EGFR}$ 変異を持つ IIIB〜 IV 期非小細胞肺癌に対する エルロチニブによる無増悪生存期間を検討する第 II 相 試験で, 2010 年に約 6 ケ月間で症例が登録された。この 症例群のサブセット解析でも 75 歳未満と 75 歳以上の各 群に打いて無増悪生存期間の中央值は 11.8 ケ月間と 12.3 ケ月間で差違を認めず, これらの結果に基づき肺癌 診療ガイドラインにおいては EGFR, 75 歳以上で PS 0 1 の症例に対してはゲフィチニブまたはエルロチニブ単 剂が推奨グレード A とされている. 同様に, ALK 融合遺 伝子を有する非小細胞肺癌にはクリゾチニブやアレクチ ニブを代表とする薬剤が高い治療効果を示すことが知ら
れている.これらの薬剤については高龄者に特化した臨 床試験はないもののその効果の高さから 75 歳以上で PS 0〜1であれば，特にアレクチニブ 29 を第 1 選択として肺 癌診療ガイドラインで推奨されている。また，近年目覚 ましい臨床成績が報告されている免疫チェックポイント 阻害薬についてもドセタキセルに対するアテゾリズマブ を比較した第 III 相試験（OAK 試験）でのサブセット解 析では, 75 歳以上の症例で生存に有意差はないものの 30 有害事象も若年者と比較して同程度である可能性があ り，より正確な効果予測因子が確立されることにより， 高齢者へのさらなる適応の拡大が期待される.

\section{おわりに}

増加の一途を辿ると想定される高齢者の非小細胞肺癌 に対する症例と治療法の適切な選択をより確実にするこ とが，臨床医にとって喫緊の課題であることは論を待た ない，症例の選択に際しては若年者でも同様であるが, 高齢者については特に個々人の人生観や死生観を含めた 治療法選択の希望が反映されるべきであろう。また厚生 労働省によると平成 22 年の男性の平均余命は 79.55 歳, 女性は 86.30 歳であるが, 日常生活に支障がない期間と 定義される健康寿命は各々 70.42 歳と 73.62 歳であり, 約 10 年間以上何らかの身体活動に影響する状況での生存 であることを示している，高齢者非小細胞肺癌の治療選 択に打いても生存と生活の質を担保することが今後より 重要となる. 高齢者非小細胞肺癌においても近年の画像 診断や外科切除に打ける周術期管理の進歩に加え, 急速 に開発が進む分子標的薬などの化学療法剤や放射線治療 
のさらなる発展に期待したい.

本論文内容に関連する著者の利益相反：なし

\section{REFERENCES}

1. Tammemagi CM, Neslund-Dudas C, Simoff M, Kvale P. In lung cancer patients, age, race-ethnicity, gender and smoking predict adverse comorbidity, which in turn predicts treatment and survival. J Clin Epidemiol. 2004;57:597609.

2. Charlson ME, Pompei P, Ales KL, MacKenzie CR. A new method of classifying prognostic comorbidity in longitudinal studies: development and validation. J Chronic Dis. 1987;40:373-383.

3. Colinet B, Jacot W, Bertrand D, Lacombe S, Bozonnat $\mathrm{MC}$, Daurès JP, et al. A new simplified comorbidity score as a prognostic factor in non-small-cell lung cancer patients: description and comparison with the Charlson's index. Br J Cancer. 2005;93:1098-1105.

4. McMillan DC, Forrest LM, O'Gorman P, Angerson WJ, McArdle CS. Performance status of male and female advanced cancer patients is independently predicted by mid-upper arm circumference measurement. Nutr Cancer. 2002;42:191-193.

5. Stuck AE, Siu AL, Wieland GD, Adams J, Rubenstein LZ. Comprehensive geriatric assessment: a meta-analysis of controlled trials. Lancet. 1993;342:1032-1036.

6. Committee for Scientific Affairs, The Japanese Association for Thoracic Surgery, Masuda M, Okumura M, Doki Y, Endo S, Hirata Y, et al. Thoracic and cardiovascular surgery in Japan during 2014: Annual report by The Japanese Association for Thoracic Surgery. Gen Thorac Cardiovasc Surg. 2016;64:665-697.

7. Shirakusa T, Tsutsui M, Iriki N, Matsuba K, Saito T, Minoda S, et al. Results of resection for bronchogenic carcinoma in patients over the age of 80. Thorax. 1989;44: 189-191.

8. Birim O, Zuydendorp HM, Maat AP, Kappetein AP, Eijkemans MJ, Bogers AJ. Lung resection for non-smallcell lung cancer in patients older than 70: mortality, morbidity, and late survival compared with the general population. Ann Thorac Surg. 2003;76:1796-1801.

9. Brock MV, Kim MP, Hooker CM, Alberg AJ, Jordan MM, Roig CM, et al. Pulmonary resection in octogenarians with stage I nonsmall cell lung cancer: a 22 -year experience. Ann Thorac Surg. 2004;77:271-277.

10. Dominguez-Ventura A, Allen MS, Cassivi SD, Nichols FC 3rd, Deschamps C, Pairolero PC. Lung cancer in octogenarians: factors affecting morbidity and mortality after pulmonary resection. Ann Thorac Surg. 2006;82:11751179 .

11. Okami J, Ito Y, Higashiyama M, Nakayama T, Tokunaga $\mathrm{T}$, Maeda J, et al. Sublobar resection provides an equivalent survival after lobectomy in elderly patients with early lung cancer. Ann Thorac Surg. 2010;90:1651-1656.

12. Shiono S, Abiko M, Sato T. Postoperative complications in elderly patients after lung cancer surgery. Interact Cardiovasc Thorac Surg. 2013;16:819-823.
13. Suemitsu R, Yamaguchi M, Takeo S, Ondo K, Ueda H, Yoshino I, et al. Favorable surgical results for patients with nonsmall cell lung cancer over 80 years old: a multicenter survey. Ann Thorac Cardiovasc Surg. 2008;14:154160.

14. Nagata Y, Hiraoka M, Shibata T, Onishi H, Kokubo M, Karasawa K, et al. Prospective Trial of Stereotactic Body Radiation Therapy for Both Operable and Inoperable T1N0M0 Non-Small Cell Lung Cancer: Japan Clinical Oncology Group Study JCOG0403. Int J Radiat Oncol Biol Phys. 2015;93:989-996.

15. Chang JY, Senan S, Paul MA, Mehran RJ, Louie AV, Balter P, et al. Stereotactic ablative radiotherapy versus lobectomy for operable stage I non-small-cell lung cancer: a pooled analysis of two randomised trials. Lancet $\mathrm{On}$ col. 2015;16:630-637.

16. Shirvani SM, Jiang J, Chang JY, Welsh J, Likhacheva A, Buchholz TA, et al. Lobectomy, sublobar resection, and stereotactic ablative radiotherapy for early-stage nonsmall cell lung cancers in the elderly. JAMA Surg. 2014;149: 1244-1253.

17. Sause W, Kolesar P, Taylor S IV, Johnson D, Livingston $\mathrm{R}$, Komaki R, et al. Final results of phase III trial in regionally advanced unresectable non-small cell lung cancer: Radiation Therapy Oncology Group, Eastern Cooperative Oncology Group, and Southwest Oncology Group. Chest. 2000;117:358-364.

18. Schild SE, Stella PJ, Geyer SM, Bonner JA, McGinnis WL, Mailliard JA, et al. The outcome of combinedmodality therapy for stage III non-small-cell lung cancer in the elderly. J Clin Oncol. 2003;21:3201-3206.

19. Atagi S, Kawahara M, Yokoyama A, Okamoto H, Yamamoto N, Ohe Y, et al. Thoracic radiotherapy with or without daily low-dose carboplatin in elderly patients with non-small-cell lung cancer: a randomised, controlled, phase 3 trial by the Japan Clinical Oncology Group (JCOG0301). Lancet Oncol. 2012;13:671-678.

20. Langer CJ, Manola J, Bernardo P, Kugler JW, Bonomi P, Cella D, et al. Cisplatin-based therapy for elderly patients with advanced non-small-cell lung cancer: implications of Eastern Cooperative Oncology Group 5592, a randomized trial. J Natl Cancer Inst. 2002;94:173-181.

21. Effects of vinorelbine on quality of life and survival of elderly patients with advanced non-small-cell lung cancer. The Elderly Lung Cancer Vinorelbine Italian Study Group. J Natl Cancer Inst. 1999;91:66-72.

22. Gridelli C, Perrone F, Gallo C, Cigolari S, Rossi A, Piantedosi F, et al. Chemotherapy for elderly patients with advanced non-small-cell lung cancer: the Multicenter Italian Lung Cancer in the Elderly Study (MILES) phase III randomized trial. J Natl Cancer Inst. 2003;95:362372.

23. Kudoh S, Takeda K, Nakagawa K, Takada M, Katakami N, Matsui K, et al. Phase III study of docetaxel compared with vinorelbine in elderly patients with advanced nonsmall-cell lung cancer: results of the West Japan Thoracic Oncology Group Trial (WJTOG 9904). J Clin Oncol. 2006;24:3657-3663.

24. Tsukada H, Yokoyama A, Goto K, Shinkai T, Harada M, 
Ando M, et al. Randomized controlled trial comparing docetaxel-cisplatin combination with weekly docetaxel alone in elderly patients with advanced non-smallcell lung cancer: Japan Clinical Oncology Group (JCOG) 0207†. Jpn J Clin Oncol. 2015;45:88-95.

25. Abe T, Takeda K, Ohe Y, Kudoh S, Ichinose Y, Okamoto $\mathrm{H}$, et al. Randomized phase III trial comparing weekly docetaxel plus cisplatin versus docetaxel monotherapy every 3 weeks in elderly patients with advanced nonsmall-cell lung cancer: the intergroup trial JCOG0803/ WJOG4307L. J Clin Oncol. 2015;33:575-581.

26. Quoix E, Zalcman G, Oster JP, Westeel V, Pichon E, Lavolé A, et al. Carboplatin and weekly paclitaxel doublet chemotherapy compared with monotherapy in elderly patients with advanced non-small-cell lung cancer: IFCT-0501 randomised, phase 3 trial. Lancet. 2011;378: 1079-1088.

27. Maemondo M, Minegishi Y, Inoue A, Kobayashi K, Harada M, Okinaga S, et al. First-line gefitinib in patients aged 75 or older with advanced non-small cell lung cancer harboring epidermal growth factor receptor mutations: NEJ 003 study. J Thorac Oncol. 2012;7:1417-1422.

28. Goto K, Nishio M, Yamamoto N, Chikamori K, Hida T, Maemondo M, et al. A prospective, phase II, open-label study (JO22903) of first-line erlotinib in Japanese patients with epidermal growth factor receptor (EGFR) mutation-positive advanced non-small-cell lung cancer (NSCLC). Lung Cancer. 2013;82:109-114.

29. Hida T, Nokihara H, Kondo M, Kim YH, Azuma K, Seto $\mathrm{T}$, et al. Alectinib versus crizotinib in patients with ALKpositive non-small-cell lung cancer (J-ALEX): an openlabel, randomised phase 3 trial. Lancet. 2017;390:29-39.

30. Rittmeyer A, Barlesi F, Waterkamp D, Park K, Ciardiello $\mathrm{F}$, von Pawel J, et al. Atezolizumab versus docetaxel in patients with previously treated non-small-cell lung cancer (OAK): a phase 3, open-label, multicentre randomised controlled trial. Lancet. 2017;389:255-265. 